\title{
SISTEM PENDUKUNG KEPUTUSAN DIAGNOSA PENYAKIT GANGGUAN JIWA DENGAN METODE DEMPSTER-SHAFER
}

\author{
Ni Wyn Nursarita Prasistayanti ${ }^{1}$, Dewa Gede Hendra Divayana ${ }^{2}$, I Made \\ Agus Wirawan ${ }^{3}$ \\ 1,2,3 Jurusan Pendidikan Teknik Informatika/Universitas Pendidikan Ganesha \\ Singaraja,Bali \\ email : prasistayanti@gmail.com¹, hendra.divayana@undiksha.ac.id², \\ agus.wirawan@undiksha.ac.id ${ }^{3}$
}

\begin{abstract}
Abstrak
Penelitian ini bertujuan: (1) Mengembangkan sistem pendukung keputusan diagnosa penyakit gangguan jiwa dengan metode Dempster-Shafer. (2) Untuk menguji kesesuaian dan tingkat akurasi sistem pendukung keputusan diagnosa penyakit gangguan jiwa dengan metode Dempster-Shafer. Penelitian ini diharapkan mampu mengatasi kendala dalam mendiagnosa penyakit gangguan jiwa yang dilakukan oleh dokter. Dalam menentukan penyakit yang diderita pasien, dokter terlebih dahulu melakukan proses konsultasi terhadap pasien. Proses konsultasi inilah yang dibantu dengan menggunakan Sistem Pendukung Keputusan (SPK). Pengambilan keputusan ini didadasarkan pada data - data rekam medis dokter sebelumnya. Metode yang digunakan untuk menentukan penyakit pasien adalah Dempster-Shafer. Jenis penelitian adalah penelitian dan pengembangan dengan model Waterfall. Implementasi penelitian ini diterapkan dengan bahasa pemrograman PHP dengan bantuan framework Laravel. Untuk proses pengujian, dilakukan empat (4) tahap proses pengujian yaitu: (1) uji whitebox yang menyatakan bahwa implementasi kode program sudah sesuai dengan spesifikasi kebutuhan, (2) uji blackbox yang menyatakan bahwa alur proses, masukan keluaran pengguna, dan fungsifungsi yang diinginkan sudah sesuai, (3) uji kesesuaian sistem yang menyatakan bahwa sistem sudah sesuai dilihat dari proses perhitungan manual dan sistem, (4) uji akurasi sistem menggunakan metode $k$-fold cross validation menyatakan bahwa persentase akurasi sistem dengan akurasi kesesuaian penuh (full accuracy) adalah $47 \%$, akurasi dengan kesesuaian sebagian (half accuracy) $32 \%$, dan tidak akurat (not accuracy) sebesar $21 \%$.
\end{abstract}

Kata kunci: Sistem Pendukung Keputusan, Diagnosa, Gangguan Jiwa, Dempster-Shafer, K-fold Cross Validation

\begin{abstract}
This study aimed to: (1) develop decision support system to diagnose mental illness with Dempster-Shafer method. (2) test suitability and accuracy degree of decision support system to diagnose mental illness. This study was supposed to prevent the obstacle in diagnosing mental illness which was conducted by the doctor. In determining the disease that was suffered by the patient, the doctor did the consultation with the patient. This process was helped by using Decision Support System. This decision based on the data of medical record by the doctor. The method that was used to decide the disease was Dempster-Shafer. Kinds of this study was research and development with Waterfall Model. The implementation of this study was applied with language programming PHP helped by Laravel framework. There are four (4) steps of testing process, namely: (1) white box testing to check that the implementation of code program had already appropriate with the specification needed, (2) black box testing to check that the plot of the process, input and output by the user, and functions that were wanted had been done. (3) suitability testing system shows that the system was already appropriate seen by the process of conventional and system, (4) accuracy testing using k-fold cross
\end{abstract}


validation shows that the percentage of accuracy of system with full accuracy was $47 \%$, half accuracy was $32 \%$, and not accuracy was $21 \%$.

Keywords : decision support system, diagnose, mental illness, Dempster-Shafer, K-fold Cross Validation.

\section{PENDAHULUAN}

Provinsi Bali dibagi menjadi 8 kabupaten dan 1 kota, serta terdiri dari 57 kecamatan. Provinsi Bali secara umum memiliki luas wilayah mencapai 5.636,66 $\mathrm{km}^{2}$. Jumlah penduduk di Bali selalu meningkat setiap tahunnya. Pada tahun 2013, jumlah penduduk di Bali adalah 4.056.300 jiwa. Meningkat di tahun berikutnya menjadi 4.104.900 jiwa. Data terakhir yang peneliti dapat, yaitu di tahun 2015 dengan jumlah penduduknya mencapai 4.125.800 jiwa. Selanjutnya, laju pertumbuhan penduduk dan kepadatan penduduk di Bali pun meningkat tiap tahunnya. Pada tahun 2015 laju pertumbuhan penduduknya adalah $1.17 \%$ dengan kepadatan penduduknya mencapai $736,7 \mathrm{~km}^{2}$. [1] Seiring meningkatnya laju pertumbuhan penduduk tiap tahunnya tentu berpengaruh terhadap keadaan penduduknya. Persaingan ketat pun tak terhindarkan. Kesenjangan sosial yang semakin tinggi di masyarakat berpengaruh terhadap kesehatan penduduk di Bali. Tidak hanya kesehatan fisik, namun juga kesehatan kejiwaan penduduknya akibat dari tekanan hidup yang semakin tinggi.

Berdasarkan hasil pencarian data yang dilakukan oleh peneliti di Dinas Kesehatan Provinsi Bali, pada tahun 2014 penderita Gangguan Mental Organik di Bali mencapai 113 orang dan meningkat di Tahun 2015 menjadi 126 orang. Peningkatan signifikan juga terjadi pada penderita gangguan jiwa akibat NAPZA yaitu, dari 1 orang menjadi 126 orang. Penderita golongan penyakit gangguan jiwa Skizofrenia dan Gangguan Psikotik lainnya pada tahun 2014 mencapai 2334 jiwa dan tahun 2015 menjadi 1751 jiwa. Tahun 2014 penderita Gangguan Bipolar mencapai 57 jiwa dan tahun berikutnya menjadi 6 jiwa. Gangguan Depresi tahun 2014 di Bali mencapai 284 orang dan meningkat menjadi 352 orang di tahun 2015. Tahun 2014 penderita Gangguan Neurotik di Bali mencapai 281 kemudian meningkat menjadi 380 orang di tahun 2015. [2] Secara keseluruhan, terjadi peningkatan jumlah penderita gangguan jiwa dari tahun 2014 hingga tahun 2015.

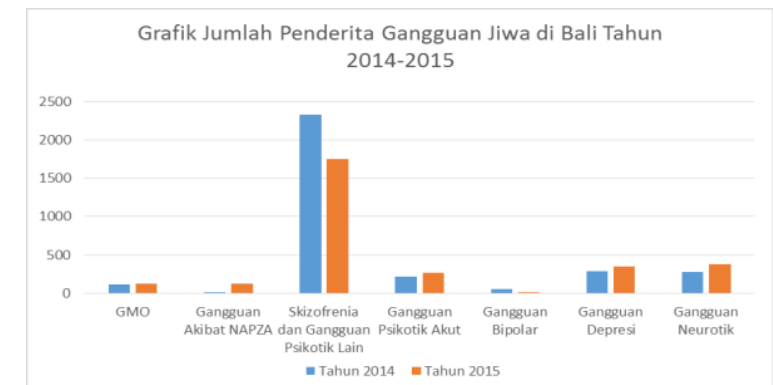

Gambar 1. Jumlah Penderita Gangguan Jiwa di Bali Tahun 2014-2015

Berbagai upaya dilakukan untuk mengurangi jumlah penderita penyakit gangguan jiwa di Bali, salah satunya adalah mengintensifkan pemeriksaan terhadap penderita penyakit gangguan jiwa. Penyakit ini memang sama pentingnya seperti penyakit fisik. Namun, dalam naan praktiknya, dokter hanya dapat menangani 2-3 pasien, tidak seperti penyakit fisik, dimana dalam sekali pemeriksaan dokter dapat menangani belasan pasien. Hal ini disebabkan karena dalam menangani penyakit gangguan jiwa memerlukan waktu yang intensif bagi dokter untuk mengenali dan mendiagnosa penyakit yang diderita pasien gangguan jiwa. Agar tidak terjadi ambigu dalam mendiagnosa gejala penyakit gangguan jiwa, keberadaan suatu sistem pendukung keputusan dibutuhkan oleh pakar dalam mendiagnosa dan menanggulangi penyakit gangguan jiwa. Salah satu dokter yang ada di Kota Denpasar yaitu Ibu dr. Putu Asih Primatanti, SpKJ. 
Berdasarkan hal tersebut peneliti termotivasi untuk mengembangkan aplikasi "Sistem Pendukung Keputusan Diagnosa Penyakit Gangguan Jiwa dengan Metode Dempster-Shafer" sebagai asisten dokter dalam mengambil keputusan penderita gangguan kejiwaan. Metode dempstershafer merupakan metode yang pertama kali dikembangkan oleh Arthur P. Dempster dan Glenn Shafer. Metode ini merupakan salah satu metode multi hipotesa, dimana dapat menghasilkan lebih dari 1 hipotesis. Dempster-Shafer Theory adalah diberlakukan sebagai suatu formula untuk menangani klasifikasi yang tidak pasti. DST juga digunakan untuk merepresentasikan keraguan, apakah ketidakpastian secara total, ataupun ketidaktahuan secara sebagian. Aturan DS merupakan aturan yang sempurna untuk ini. [3] Penderita gangguan jiwa sangat mungkin menderita lebih dari satu penyakit yang dalam hal ini disebut "komorbiditas". Maka dari itu, peneliti menggunakan metode DempsterShafer untuk memberikan nilai kepastian. Sistem ini juga akan dibangun berbasis web sehingga dapat diakses oleh dokter kapanpun dan dimanapun dengan berbagai platform. Diharapkan nantinya sistem ini dapat membantu pakar dalam melakukan diagnosa dan penanggulangan terhadap gangguan kejiwaan lebih efektif.

\section{KAJIAN TEORI}

A. IImu Jiwa dan Gangguan Kejiwaan

IImu jiwa atau psikologi adalah suatu cabang dari ilmu pengetahuan yang mempelajari, menyelidiki, atau membahas fungsi - fungsi kejiwaan dari orang yang sehat. Atau dengan perkataan lain psikologi mempelajari aktivitas kehidupan kejiwaan dari orang normal. Psikologi (Ilmu Jiwa) ialah ilmu yang mempelajari segala aktivitas jiwa, yaitu yang mencakup segala sesuatu yang diperbuat oleh manusia yang terwujud dalam kegiatan manusia (human activities). [4] Sedangkan, sakit jiwa adalah gangguan mental yang berdampak kepada mood, pola pikir, hingga tingkah laku secara umum. Seseorang disebut mengalami sakit jiwa jika gejala yang dialaminya menyebabkan sering stres dan menjadikannya tidak mampu melakukan aktivitas sehari-hari secara normal. Penggolongan penyakit gangguan jiwa menurut PPDGJ III dapat dilihat pada Gambar 2.

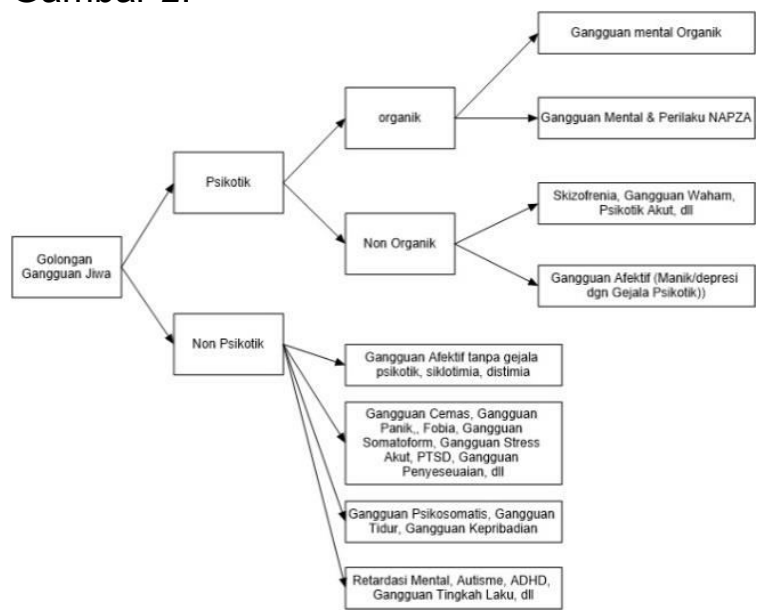

Gambar 2. Penggolongan Penyakit Gangguan Jiwa berdasarkan PPDGJ III [5]

B. Sistem Pendukung Keputusan

1. Definisi SPK

Menurut Alter (2002) SPK merupakan sistem informasi interaktif yang menyediakan informasi, pemodelan, dan pemanipulasian data. Selain itu digunakan untuk membantu pengambilan keputusan dalam situasi semi terstruktur dan situasi yang tidak terstruktur, dimana tak seorang pun tahu secara pasti bagaimana keputusan seharusnya dibuat. [6]

Sistem pendukung keputusan (Inggris: decision support systems disingkat $D S S$ ) adalah bagian dari sistem informasi berbasis komputer (termasuk sistem berbasis pengetahuan (manajemen pengetahuan) yang dipakai untuk mendukung pengambilan keputusan dalam suatu organisasi atau perusahaan. Dapat juga dikatakan sebagai sistem komputer yang mengolah data menjadi informasi untuk mengambil keputusan dari masalah semi-terstruktur yang spesifik. [7]

SPK adalah pendekatan berbasis komputer atau metodologi untuk mendukung pengambilan keputusan. Bagian paling penting dari SPK khas adalah data warehouse, yang merupakan subjek berorientasi, terpadu, waktu-varian, 
non-normalisasi, koleksi non-volatile data yang memungkinkan menganalisis sejumlah besar data dari berbagai sumber dengan hasil yang cepat. [8]

\section{Komponen (subsistem) SPK}

SPK terdiri dari beberapa komponen, berikut ini adalah komponen SPK. [9] Komponen-komponen sistem pendukung keputusan dapat dilihat pada Gambar 3.

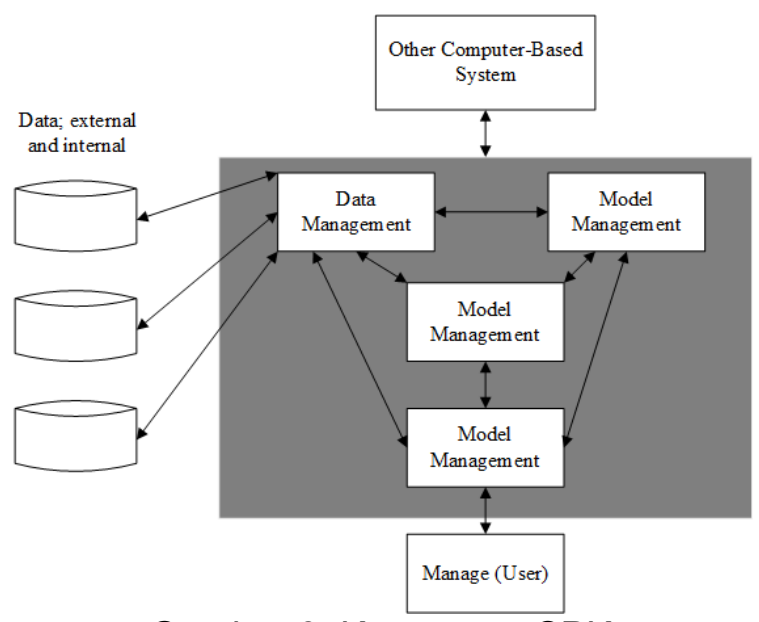

Gambar 3. Komponen SPK

\section{Teori Dempster-Shafer}

Teori Dempster-Shafer adalah suatu teori matematika untuk pembuktian berdasarkan belief functions and plausible reasoning (fungsi kepercayaan dan pemikiran yang masuk akal), yang digunakan untuk mengkombinasikan potongan informasi yang terpisah (bukti) untuk mengkalkulasi kemungkinan dari suatu peristiwa. Teori ini dikembangkan oleh Arthur P. Dempster dan Glenn Shafer. [10] Secara umum Teori Dempster-Shafer ditulis dalam suatu interval:

[Belief, Plausibility]

\section{Belief}

Belief (Bel) adalah ukuran kekuatan evidence (gejala) dalam mendukung suatu himpunan bagian. Jika bernilai 0 maka mengindikasikan bahwa tidak ada evidence, dan jika bernilai 1 menunjukan adanya kepastian.

\section{Plausibility}

Plausibility (PI) dinotasikan sebagai:

$\operatorname{Pl}(s)=1-\operatorname{Bel}(\neg s)-$
Untuk mengatasi sejumlah evidence pada teori Dempster-Shafer menggunakan aturan yang lebih dikenal dengan Dempster's Rule of Combination.

$M_{3}(\mathrm{Z})=\frac{\sum_{\mathrm{X} \cap Y=z} m_{1}(X) \cdot m_{2}(Y)}{1-\boldsymbol{K}}$

Dimana $\kappa=\sum_{X \cap Y=\varnothing} m_{1}(X) \cdot m_{2}(Y)$

Dengan:

$m_{1}(X)$ : mass function dari evidence $X$ $\mathrm{m}_{2}(\mathrm{Y})$ : mass function dari evidence $\mathrm{Y}$ $\mathrm{m}_{3}(Z)$ : mass function dari evidence $Z$ $\mathrm{K}$ : jumlah conflict evidence

\section{K-fold Cross Validation}

$N$-fold cross validation atau $k$-fold cross validation merupakan salah satu metode yang digunakan untuk mengetahui rata-rata keberhasilan dari suatu sistem dengan cara melakukan perulangan dengan mengacak atribut masukan sehingga sistem tersebut teruji untuk beberapa atribut input yang acak. K-fold cross validation adalah sebuah teknik intensif komputer yang menggunakan keseluruhan data sebagai training set dan test set. $N$-fold cross validation diawali dengan membagi data sejumlah $n$-fold yang diinginkan. Dalam proses cross validation data akan dibagi dalam $\mathrm{n}$ buah partisi dengan ukuran yang sama D1,D2,D3..Dn selanjutnya proses testing dan training dilakukan sebanyak $\mathrm{n}$ kali. Dalam iterasi ke-i partisi Di akan menjadi data testing dan sisanya akan menjadi data training. [11] Rumus untuk menghitung nilai akurasi dilakukan dengan menggunakan persamaan berikut.

Akurasi $=\frac{\text { Jumlah rekomendasi yang sesuai }}{\text { jumlah heseluruhan rekomendasi }} x 100 \%$

\section{E. Framework Laravel}

Laravel adalah framework PHP dengan kode terbuka (open source) dengan desain MVC (Model-ViewController) yang digunakan untuk membangun aplikasi website. Framework ini pertama kali dibangun oleh Taylor Otwell pada tanggal 22 Pebruari 2012 dengan fitur-fitur baru yang tidak ada di framework 
lain, seperti Autoloading, Unit Testing, dll. Kemudian Laravel dilengkapi juga dengan command line tool yang bernama "Artisan" yang dapat digunakan untuk packaging bundle dan instalasi bundle melalui command prompt. [12].

\section{METODOLOGI}

A. Analisis Perangkat Lunak

Berikut adalah cara untuk menentukan penyakit pasien dengan metode Dempster-Shafer. Diketahui data rekam medis pada Tabel 1.

Tabel 1. Data Rekam Medis

\begin{tabular}{|c|c|c|}
\hline $\begin{array}{l}\text { Kode } \\
\text { Pasien }\end{array}$ & Gejala & Penyakit \\
\hline Ps1 & $\begin{array}{l}\text { G1 } \\
\text { G2 } \\
\text { G3 } \\
\text { G9 }\end{array}$ & P1 \\
\hline Ps2 & $\begin{array}{l}\mathrm{G} 4 \\
\mathrm{G} 2 \\
\mathrm{G} 5\end{array}$ & P2 \\
\hline Ps3 & $\begin{array}{l}\text { G6 } \\
\text { G7 } \\
\text { G2 } \\
\text { G8 } \\
\text { G9 } \\
\text { G5 } \\
\text { G10 } \\
\text { G11 }\end{array}$ & $\begin{array}{l}\text { P3 } \\
\text { P4 }\end{array}$ \\
\hline Ps4 & G12 & P5 \\
\hline Ps5 & $\begin{array}{l}\text { G13 } \\
\text { G14 } \\
\text { G15 } \\
\text { G2 } \\
\text { G5 }\end{array}$ & P6 \\
\hline Ps6 & $\begin{array}{l}\text { G16 } \\
\text { G17 } \\
\text { G18 }\end{array}$ & P6 \\
\hline Ps7 & $\begin{array}{l}\text { G19 } \\
\text { G5 } \\
\text { G2 } \\
\text { G20 }\end{array}$ & P7 \\
\hline Ps8 & \begin{tabular}{|l|}
$G 21$ \\
G22 \\
G5 \\
G2 \\
G23 \\
G24
\end{tabular} & $\begin{array}{l}\text { P8 } \\
\text { P2 } \\
\text { P9 }\end{array}$ \\
\hline Ps9 & $\begin{array}{l}\mathrm{G} 1 \\
\mathrm{G} 2 \\
\mathrm{G} 61 \\
\mathrm{G} 15\end{array}$ & P10 \\
\hline
\end{tabular}

\begin{tabular}{|l|l|l|}
\hline $\begin{array}{l}\text { Kode } \\
\text { Pasien }\end{array}$ & Gejala & Penyakit \\
\hline Ps10 & G25 & P11 \\
& G15 & P12 \\
& G1 & \\
& G23 & \\
\hline G2 & G1 & \\
\hline Ps11 & G2 & \\
& G15 & \\
\hline
\end{tabular}

Keterangan:

Ps : Pasien

G1 : Depresif

G2 : Insomnia

G3 : Kesulitan konsentrasi

G4 : Gangguan tidur

G5 : Cemas

G6 : Serangan panik

G7 : Sering kalut

G8 : Dada berdebar

G9 : Sakit kepala

G10 : Takut dijebak

G11 : Lelah/capek tidak jelas

G12 : Depresi masalah rumah tangga

G13 : Impulsivitas

G14 : Merasa kesepian

G15 : Mood tidak stabil

G16 : Merasa down

G17 : Sedih

G18 : Acting out saat pelepasan emosi

G19 : Mogok sekolah

G20 : Keras pendirian

G21 : Sering kaget

G22 : Mengomel sendiri

G23 : Waham

G24 : Halusinasi

G25 : Stress pekerjaan

G61 : Gangguan proses pikir/preokupasi

P1 : Gg. Episode Depresi dgn Gg.

Somatik

P2 : Gg. Cemas

P3 : Gg. Panik

P4 : Gg. Episode Depresi Sedang dgn Gg. Somatik

P5 : Marriage problem

P6 : Gg. Depresi dan impulsive obesif

P7 : Gg. Conduet

P8 : GMP

P9 : Gg. Depresi dgn Gg. Psikotik

P10 : Gg. Depresi tanpa Gg. Psikotik

P11 : Gg. Penyesuaian

P12 : Gg. Depresi Berkepanjangan 
1. Menghitung Nilai Probabilitas Kemungkinan Penyakit Berdasarkan Gejala

Perhitungan Dempster-Shafer memerlukan nilai densitas $(\mathrm{m})$ awal terdiri dari belief dan plausibility. Nilai belief dan plausibility ditentukan terlebih dahulu dari probabilitas berdasarkan data yang ada pada Tabel 2 .

Tabel 2. Probabilitas Penyakit Terhadap G1

\begin{tabular}{|c|c|c|}
\hline Kemungkinan & \multicolumn{2}{|l|}{ Probabilitas } \\
\hline$P(G 1 \mid P 1)$ & $1 / 3$ & 0,333333333 \\
\hline$P(G 1 \mid P 10)$ & $1 / 3$ & 0,333333333 \\
\hline $\begin{array}{l}P(G 1 \mid P 11, \\
P 12)\end{array}$ & $1 / 3$ & 0,333333333 \\
\hline Plausibility $(\Theta)$ & $\begin{array}{l}1- \\
(0,33333333 \\
3+ \\
0,333333333 \\
+0,33333333 \\
3)\end{array}$ & 0 \\
\hline
\end{tabular}

Tabel 3. Probabilitas Penyakit Terhadap G2

\begin{tabular}{|c|c|c|}
\hline Kemungkinan & Probabilitas & \\
\hline$P(G 2 \mid P 1)$ & $1 / 8$ & 0,125 \\
\hline$P(G 2 \mid P 2)$ & $1 / 8$ & 0,125 \\
\hline$P(G 2 \mid P 3, P 4)$ & $1 / 8$ & 0,125 \\
\hline$P(G 2 \mid P 6)$ & $1 / 8$ & 0,125 \\
\hline$P(G 2 \mid P 7)$ & $1 / 8$ & 0,125 \\
\hline$P(G 2 \mid P 8, P 2, P 9)$ & $1 / 8$ & 0,125 \\
\hline$P(G 2 \mid P 10)$ & $1 / 8$ & 0,125 \\
\hline $\mathrm{P}(\mathrm{G} 2 \mid \mathrm{P} 11, \mathrm{P} 12)$ & $1 / 8$ & 0,125 \\
\hline Plausibility $(\Theta)$ & $\begin{array}{l}1-(0,125+ \\
0,125+ \\
0,125+ \\
0,125+ \\
0,125+ \\
0,125+ \\
0,125+ \\
0,125)\end{array}$ & 0 \\
\hline
\end{tabular}

Tabel 4. Probabilitas Penyakit terhadap G15

\begin{tabular}{|l|l|l|}
\hline $\begin{array}{l}\text { Kemungkinan } \\
\text { penyakit }\end{array}$ & \multicolumn{2}{|l|}{ Probabilitas } \\
\hline $\mathrm{P}(\mathrm{G} 15 \mid \mathrm{P} 6)$ & $1 / 3$ & 0,33333 \\
\hline
\end{tabular}

\begin{tabular}{|l|l|l|}
\hline & & 3333 \\
\hline $\mathrm{P}(\mathrm{G} 15 \mid \mathrm{P} 10)$ & $1 / 3$ & 0,33333 \\
& & 3333 \\
\hline $\mathrm{P}(\mathrm{G} 15 \mid$ & $1 / 3$ & 0,33333 \\
$\mathrm{P} 11, \mathrm{P} 12)$ & & 3333 \\
\hline Plausibility $(\Theta)$ & $1-$ & 0 \\
& 0,333333333 & \\
& + & \\
& $0,333333333+$ & \\
& $0,333333333)$ & \\
\hline
\end{tabular}

2. Menghitung Nilai Dempster-Shafer Selanjutnya, nilai belief dan plausibility digunakan dalam perhitungan dempstershafer. Pertama, dilakukan kombinasi $\mathrm{m}_{1}$ dengan $\mathrm{m}_{2}$ dengan gejala depresif (G1) dan insomnia (G2) untuk kemudian mendapatkan nilai $\mathrm{m}_{3}$. 
Tabel 5. Kombinasi G1 dan G2

\begin{tabular}{|c|c|c|c|c|c|c|c|c|c|c|}
\hline \multirow{2}{*}{$\mathrm{m} 1$} & P1 & P2 & P3,P4 & P6 & $\mathrm{P} 7$ & $\mathrm{P} 8, \mathrm{P} 2, \mathrm{P} 9$ & P10 & \multicolumn{2}{|c|}{$\mathrm{P} 11, \mathrm{P} 12$} & $\Theta$ \\
\hline & 0,125 & 0,125 & 0,125 & 0,125 & 0,125 & 0,125 & 0,125 & \multicolumn{2}{|c|}{0,125} & 0 \\
\hline P1 & P1 & \{\} & \{\} & \{\} & \{\} & \{\} & \{\} & \multicolumn{2}{|l|}{} & P1 \\
\hline 0.333333 & 0,041667 & 0,041667 & 0,041667 & 0,041667 & 0,041667 & 0,041666667 & 0,041667 & \multicolumn{2}{|c|}{0,041667} & 0 \\
\hline $\mathrm{P} 10$ & \{\} & \{\} & \{\} & \{\} & \{\} & \{\} & P10 & \multicolumn{2}{|l|}{} & P10 \\
\hline 0.333333 & 0,041667 & 0,041667 & 0,041667 & 0,041667 & 0,041667 & 0,041666667 & 0,041667 & \multicolumn{2}{|c|}{0,041667} & 0 \\
\hline $\mathrm{P} 11, \mathrm{P} 12$ & \{\} & \{\} & \{\} & \{\} & \{\} & \{\} & \{\} & $\mathrm{P} 11, \mathrm{P} 1$ & & P11, \\
\hline 0.333333 & 0,041667 & 0,041667 & 0,041667 & 0,041667 & 0,041667 & 0,041666667 & 0,041667 & 0,0416 & & \\
\hline$\Theta$ & $\mathrm{P} 1$ & $\mathrm{P} 2$ & P3,P4 & P6 & P7 & P8,P2,P9 & $\mathrm{P} 10$ & $\mathrm{P} 11, \mathrm{P} 1$ & & $\Theta$ \\
\hline 0 & 0 & 0 & 0 & 0 & 0 & 0 & c & & 0 & \\
\hline & aniutnva & ihitung $n$ & denga & a & $m_{3}$ & $\begin{array}{r}0,3333 \\
33\end{array}$ & $\begin{array}{r}0,3333 \\
33\end{array}$ & $\begin{array}{r}0,3333 \\
33\end{array}$ & & 0 \\
\hline & $\operatorname{dan}(5) \mathrm{se}$ & . Intury & derlyc & & $\mathrm{P} 1$ & \{\} & \{\} & \{\} & $\mathrm{P} 1$ & \\
\hline $\begin{array}{l}\text { (4) } \\
\text { Tot }\end{array}$ & $\begin{array}{l}\text { dan (b) se } \\
\text { la Konflik }\end{array}$ & erlk & & & $\begin{array}{r}0,3333 \\
33\end{array}$ & $\begin{array}{r}0,1111 \\
11\end{array}$ & $\begin{array}{r}0,1111 \\
11\end{array}$ & $\begin{array}{r}0,1111 \\
11\end{array}$ & & 0 \\
\hline & $=$ & & & & $\mathrm{P} 2$ & \begin{tabular}{l|l} 
& \{\} \\
\end{tabular} & \{\} & \{\} & $\mathrm{P} 2$ & \\
\hline & $1667+0,0$ & $11667+0,0$ & $11667+0,0$ & $41667+$ & & 0 & 0 & 0 & & 0 \\
\hline 0,04 & $1666667+$ & $0,041667+$ & 0,041667 & & P3,P4 & \{\} & \{\} & \{\} & $\mathrm{P} 3, \mathrm{I}$ & $\mathrm{P} 4$ \\
\hline 0,04 & $1667+0,0$ & $11667+0$. & $41667+0$ & $41667+$ & & 0 & 0 & 0 & & $\underline{0}$ \\
\hline & $1667+0,0$ & $\$ 1666667+$ & 0,041667 & & P6 & P6 & \{\} & \{\} & P6 & \\
\hline & $41667+0$ & $41667+0$ & $041667+$ & & & 0 & 0 & 0 & & $\underline{0}$ \\
\hline 0,04 & $1667+0,0$ & $\$ 1667+0,0$ & 41666667 & & P7 & \{\} & \{\} & \{\} & P7 & \\
\hline 0,0 & $1667=0,8$ & & & & & 0 & 0 & 0 & & 0 \\
\hline & & & & & P9 & \{\} & \{\} & \{\} & & \\
\hline$m_{3}$ & & $=\frac{0+0,04166}{1-0,975}$ & ${ }^{+0}=0,333$ & & & 0 & 0 & 0 & & $\underline{0}$ \\
\hline & & $=0$ & & & P10 & \{\} & P10 & \{\} & P10 & \\
\hline$m_{3}$ & & $=\overline{1-0,875}$ & & & $\begin{array}{r}0,3333 \\
33\end{array}$ & $\begin{array}{r}0,1111 \\
11\end{array}$ & $\begin{array}{r}0,1111 \\
11\end{array}$ & $\begin{array}{r}0,1111 \\
11\end{array}$ & & 0 \\
\hline$m_{3}$ & $P 3, P 4\}$ & $=\overline{1-0,875}=$ & & & $\begin{array}{l}\mathrm{P} 11, \mathrm{P} 1 \\
2\end{array}$ & \{\} & \{\} & $\begin{array}{l}\mathrm{P} 11, \mathrm{P} 1 \\
2\end{array}$ & & $1, \mathrm{P} 1$ \\
\hline$m_{3}$ & & $=\frac{0}{1-0,975}=$ & & & 0,3333 & 0,1111 & 0,1111 & 0,1111 & & \\
\hline$m_{3}$ & & $0=$ & & & 33 & 11 & 11 & 11 & & $\underline{0}$ \\
\hline & $8, P 2, P G$ & $=\frac{\begin{array}{c}1-0,875 \\
0\end{array}}{}=$ & & & $\Theta$ & P6 & P10 & $\begin{array}{l}\mathrm{P} 11, \mathrm{P} 1 \\
2\end{array}$ & $\Theta$ & \\
\hline & & $\begin{array}{l}1-0,875 \\
0,041667 .\end{array}$ & 0. $-2+2$ & & & 0 & 0 & 0 & & $\underline{0}$ \\
\hline
\end{tabular}

$\mathrm{m}_{3}\{\mathrm{P} 10\}=\frac{0,041667+0+0}{1-0,875}=0,333333$

$\mathrm{m}_{3}\{\mathrm{P} 11, \mathrm{P} 12\}=\frac{0,041667+0+0}{1-0,875}=0,333333$

$\mathrm{m}_{3}\{\Theta\} \quad=\frac{0}{1-0,875}=0$

Setelah didapat nilai $\mathrm{m}_{3}$, dengan cara yang sama, lakukan kombinasi kedua nilai $\mathrm{m}_{3}$ dan $\mathrm{m}_{4}$ untuk kemudian didapatkan nilai $\mathrm{m}_{5}$.

Selanjutnya dihitung lagi $m_{5}$ dengan formula (4) dan (5) sebagai berikut. Total Konflik

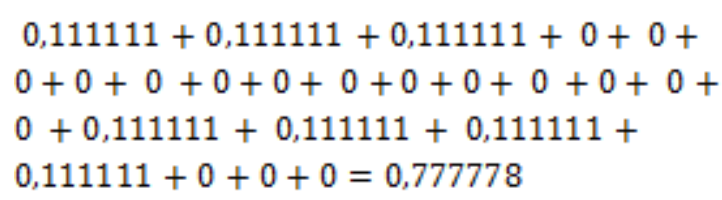

Tabel 6. Kombinasi $m_{3}$ dan $\mathrm{G} 15$

\begin{tabular}{l|l|l|l|l}
$\mathrm{m}_{4}$ & $\mathrm{P} 6$ & $\mathrm{P} 10$ & $\mathrm{P} 11, \mathrm{P} 1$ & \\
\end{tabular}




$$
\begin{array}{ll}
\mathrm{m}_{5}\{\mathrm{P} 1\} & =\frac{0}{1-0,77778}=0 \\
\mathrm{~m}_{5}\{\mathrm{P} 2\} & =\frac{0}{1-0,777778}=0 \\
\mathrm{~m}_{5}\{\mathrm{P} 3, \mathrm{P} 4\} & =\frac{0}{1-0,777778}=0 \\
\mathrm{~m}_{5}\{\mathrm{P} 6\} & =\frac{0+0+0}{1-0,77778}=0 \\
\mathrm{~m}_{5}\{\mathrm{P} 7\} & =\frac{0}{1-0,777778}=0 \\
\mathrm{~m}_{5}\{\mathrm{P} 8, \mathrm{P} 2, \mathrm{P} 9\} & =\frac{0}{1-0,777778}=0 \\
\mathrm{~m}_{5}\{\mathrm{P} 10\} & =\frac{0.111111+0+0}{1-0,777778}=0,49999 \\
\mathrm{~m}_{5}\{\mathrm{P} 11, \mathrm{P} 12\} & =\frac{0.111111+0+0}{1-0,777778}=0,49999 \\
\mathrm{~m}_{5}\{\Theta\} & =\frac{0}{1-0,77778}=0
\end{array}
$$

Jadi, pasien 11 di diagnosa menderita gangguan episode depresi tanpa gangguan psikotik (P10) dengan gangguan penyesuaian \& gangguan depresi berkepanjangan (P11,P12) dengan nilai kepercayaan masing-masing 0,49999.

B. Model Fungsional Perangkat Lunak Model fungsional perangkat lunak menjelaskan gambaran umum terhadap proses yang terjadi dalam perangkat lunak. Dari hasil analisis sistem yang dilakukan maka untuk menyelesaikan masalah tersebut dapat dibuat suatu rancangan sistem pendukung keputusan diagnosa penyakit gangguan jiwa. Rancangan SPK ini akan digambarkan dengan menggunakan Data Flow Diagram (DFD). Berikut merupakan Diagram Level 1 dari sistem pendukung keputusan diagnosa penyakit gangguan jiwa dengan metode dempster-shafer dapat dilihat pada Gambar 4.

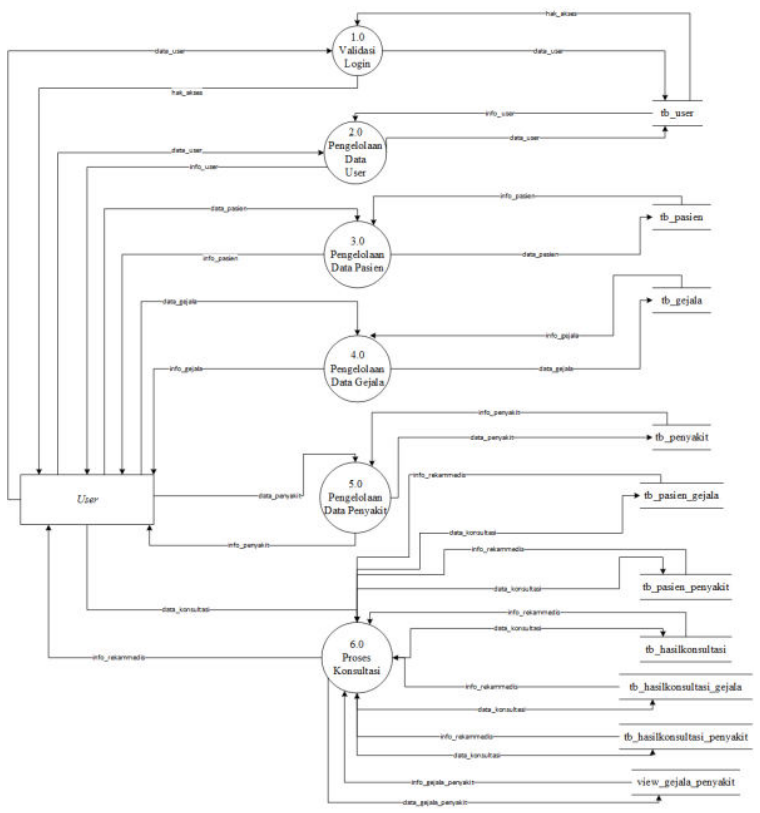

Gambar 4. Diagram Level 1

\section{PEMBAHASAN}

A. Implementasi Antarmuka Perangkat Lunak

Adapun implementasi tampilan antarmuka perangkat lunak Sistem Pendukung Keputusan Diagnosa Penyakit Gangguan Jiwa dengan Metode DempsterShafer adalah sebagai berikut.

\section{a. Antarmuka Halaman Awal}

Halaman awal adalah halaman yang pertama kali muncul saat user mengakses alamat sistem. Implementasi antarmuka halaman awal sistem dapat digambarkan seperti pada Gambar 5.

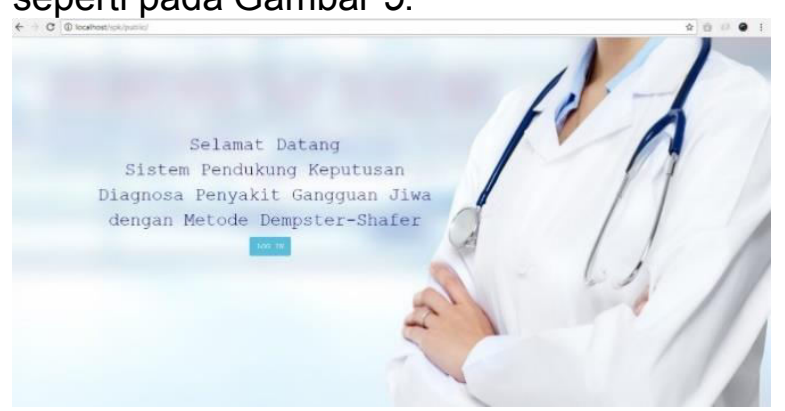

Gambar 5. Antarmuka Halaman Awal

\section{b. Antarmuka Halaman Login}

Sebelum user masuk ke halaman utama, user harus login terlebih dahulu dengan username dan password yang sudah ada. Implementasi antarmuka 
halaman login sistem dapat digambarkan seperti pada Gambar 6.

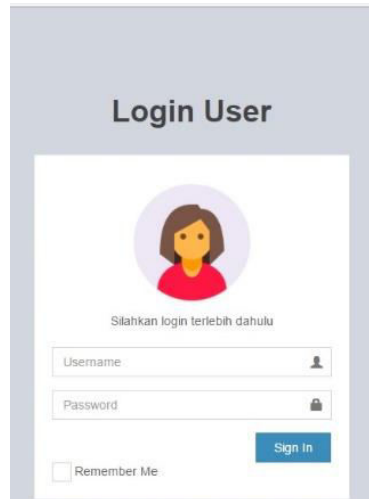

Gambar 6. Antarmuka Halaman Login

c. Antarmuka Halaman Utama (Dashboard)

Halaman utama adalah halaman yang muncul setelah user berhasil login sistem. Halaman utama terdiri dari beberapa menu yang akan diakses user. Implementasi antarmuka halaman awal sistem dapat digambarkan seperti pada Gambar 7.

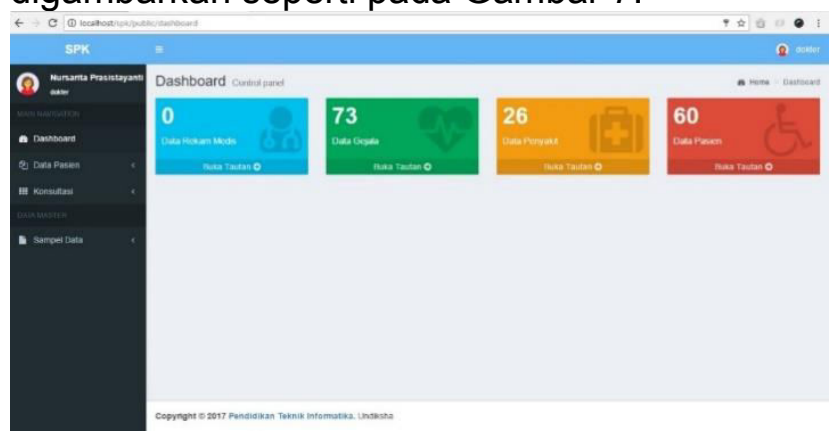

Gambar 7. Antarmuka Halaman Utama (Dashboard)

\section{d. Antarmuka Halaman Detail Data Profil User}

Halaman detail data profil user adalah halaman yang menampilkan profil user. Implementasi antarmuka halaman detail data profil user dapat digambarkan seperti pada Gambar 8.

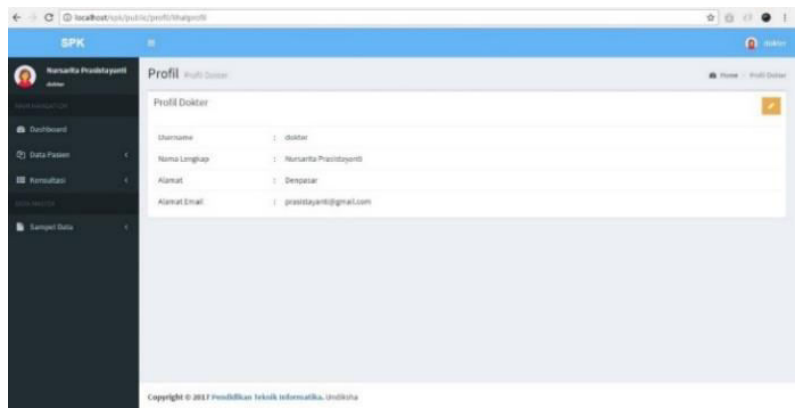

Gambar 8. Antarmuka Halaman Detail Data Profil User

\section{e. Antarmuka Halaman Ubah Data Profil User}

Halaman ubah data profil user adalah halaman yang digunakan user untuk mengubah data profil. Implementasi antarmuka halaman ubah data profil user dapat digambarkan seperti pada Gambar 9.

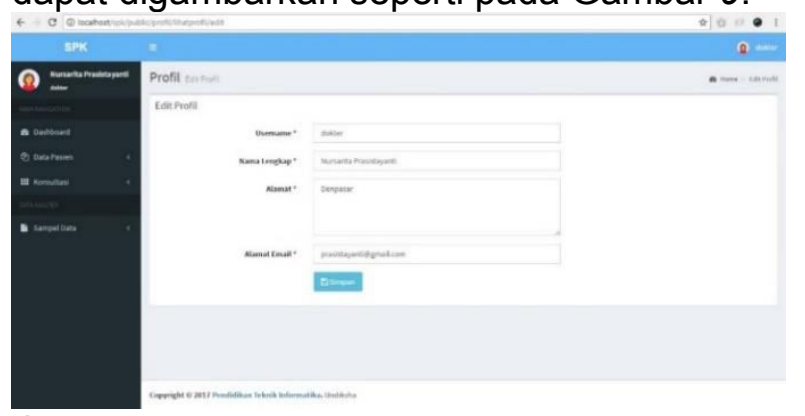

Gambar 9. Antarmuka Halaman Ubah Data Profil User

\section{f. Antarmuka Halaman Tambah Data Pasien}

Halaman tambah data pasien adalah halaman yang digunakan user untuk menambah data pasien. Implementasi antarmuka halaman tambah data pasien dapat digambarkan seperti Gambar 10.

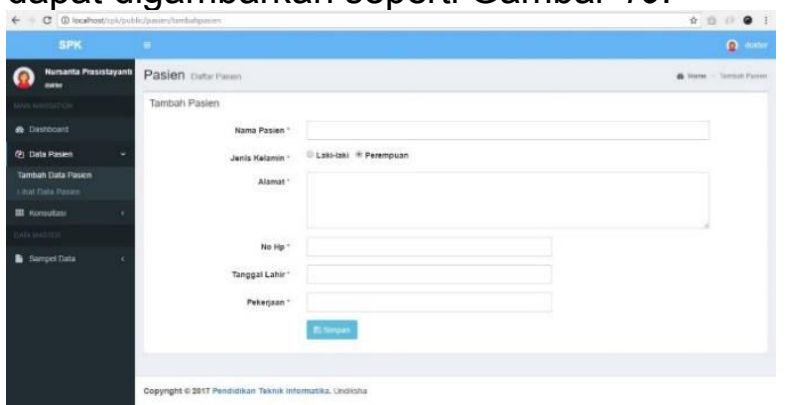

Gambar 10. Antarmuka Halaman Tambah Data Pasien 
g. Antarmuka Halaman Lihat Data Pasien

Halaman lihat data pasien adalah halaman yang menampilkan data pasien yang sudah terdaftar. Implementasi antarmuka halaman lihat data pasien dapat digambarkan seperti pada Gambar 11.

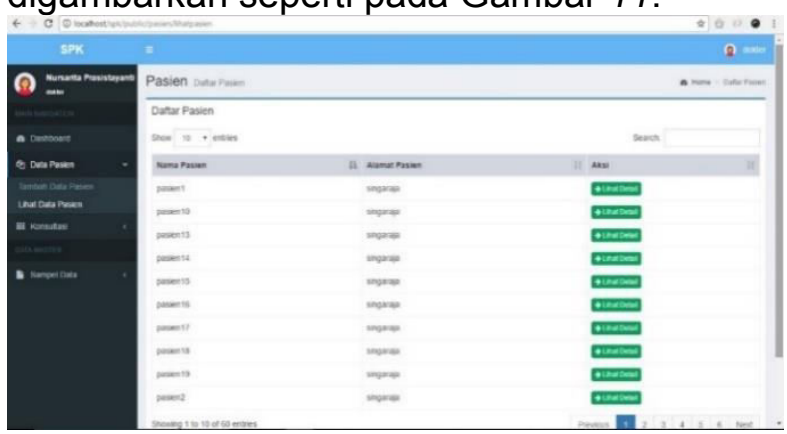

Gambar 11. Antarmuka Halaman Lihat Data Pasien

\section{h. Antarmuka Halaman Detail Data Pasien}

Halaman detail data pasien adalah halaman yang menampilkan data per pasien yang sudah terdaftar secara detail. Implementasi antarmuka halaman detail data pasien dapat digambarkan seperti pada Gambar 12.

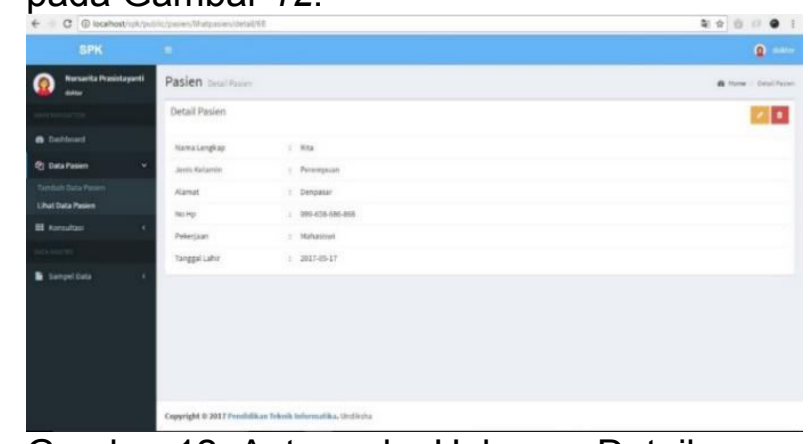

Gambar 12. Antarmuka Halaman Detail Data Pasien

\section{i. Antarmuka Halaman Ubah Data Pasien}

Halaman ubah data pasien adalah halaman yang mengubah data pasien yang sudah terdaftar. Implementasi antarmuka halaman ubah data pasien dapat digambarkan seperti pada Gambar 13.

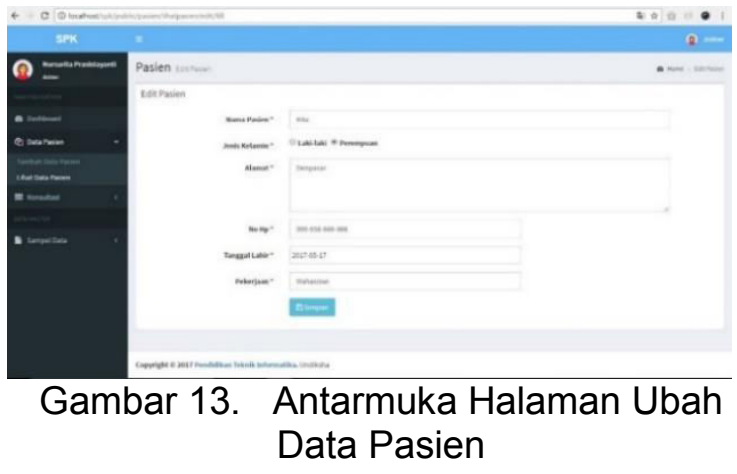

j. Antarmuka Halaman Proses Konsultasi Halaman proses konsultasi adalah halaman yang digunakan user untuk melakukan konsultasi terhadap pasien. Implementasi antarmuka halaman proses konsultasi dapat digambarkan seperti pada Gambar 14.

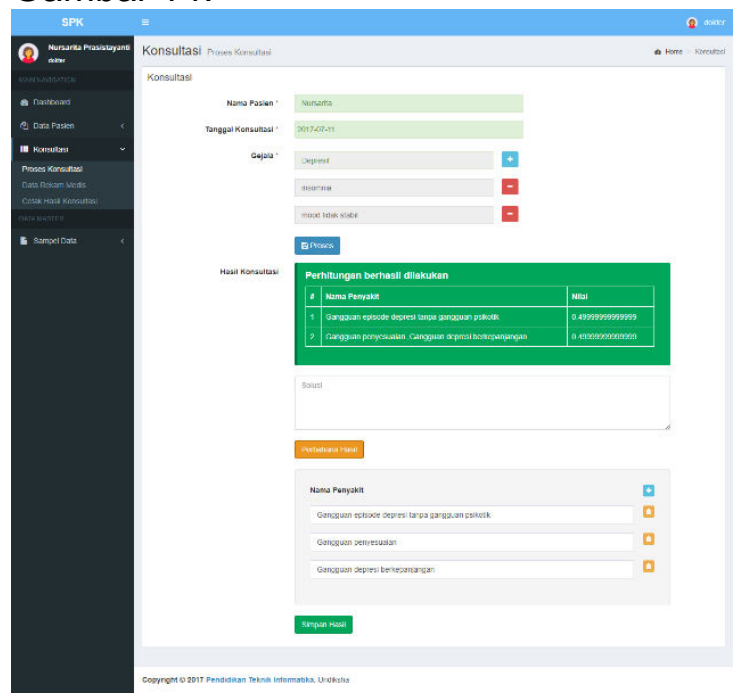

Gambar 14. Antarmuka Halaman Proses Konsultasi

\section{k. Antarmuka Halaman Rekam Medis}

Halaman data rekam medis adalah halaman yang menampilkan data hasil proses konsultasi. Implementasi antarmuka halaman rekam medis dapat digambarkan seperti pada Gambar 15. 


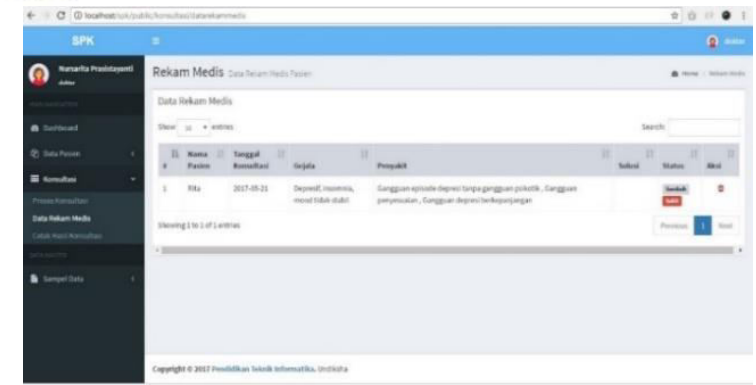

Gambar 15. Antarmuka Halaman Rekam Medis

\section{Antarmuka Halaman Cetak Data}

Halaman cetak data adalah halaman yang digunakan user untuk mencetak data konsultasi. Baik berdasarkan nama pasien, maupun berdasarkan tanggal konsultasi. Implementasi antarmuka halaman cetak data dapat digambarkan seperti pada Gambar 16.

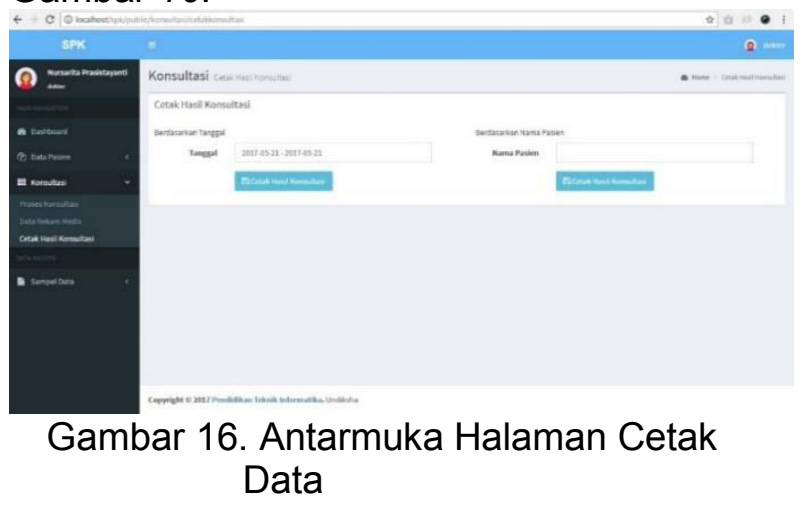

\section{B. Hasil Pengujian Perangkat Lunak}

Pengujian perangkat lunak terdiri dari black box testing, white box testing dan pengujian tingkat keakuratan sistem. Pengujian black box perangkat lunak ini terdiri 1 uji kasus yang memiliki tujuan untuk menguji fungsionalitas perangkat lunak Pengujian white box, yaitu pengujian kebenran pengimplementasian proses dan algoritma yang dibutuhkan dalam menghitung nilai probabilitas data baru dan proses pemberian rekomendasi keputusan. Proses pengujian tingat keakuratan sistem yaitu, pengujian tingkat keakuratan sistem dengan menggunakan model $k$-fold cross validation. Dari pelaksanaan masingmasing kasus uji diperoleh untuk pengujian black box yang terdiri dari pelaksanaan uji kasus yang dilakukan pengguna dan ahli media mengenai fungsional perangkat lunak sudah sesuai.
Dari pelaksanaa pengujian tingkat keakuratan dengan menggunakan model $k$ fold cross validation dimana jumlah data yang digunakan dalam pengujian ini adalah 100 data. Jumlah $\mathrm{k}$ yang digunakan dalam pegujian ini adalah 4, sehingga masingmasing fold untuk data rekam medis adalah sejumlah 25 data. Untuk iterasi 1 fold 1 digunakan sebagai data testing fold 2, fold 3 , dan fold 4 digunakan sebagai data training. Untuk iterasi 2 fold 2 digunakan sebagai data testing fold 1 , fold 3 , dan kan sebagai data training. Untuk Iterasi 3 fold 3 digunakan sebagai data testing fold 1 , fold 2, dan fold 4 digunakan sebagai data training. Untuk Iterasi 4 fold 4 digunakan sebagai data testing fold 1, fold 2, dan fold 3 digunakan sebagai data training. Dari hasil pengujian tingkat keakuratan sistem diperoleh hasil tingkat keakuratan sebagai berikut diperoleh hasil full accuracy (FA) sebesar $47 \%$, sedangkan half accuracy (HA) sebesar $32 \%$ dan not accuracy (NA) sebesar $21 \%$.

\section{SIMPULAN}

Rancangan Pengembangan Sistem Pendukung Keputusan Diagnosa Penyakit Gangguan Jiwa menggunakan metode penelitian Waterfall dan metode Dempster-Shafer yang digunakan sebagai metode dalam acuan perhitungan untuk pemberian keputusan diagnosa penyakit gangguan jiwa dengan metode dempster-shafer berupa sebuah sistem pendukung keputusan yang mampu untuk mengolah data pasien, melakukan proses konsultasi, merekam data konsultasi, dan mencetak data konsultasi. Hasil pengujian akurasi sistem dengan 100 data rekam medis yang terdiri dari 80 data gejala dan 36 data penyakit menggunakan metode $k$-fold cross validation mendapatkan hasil sebesar diperoleh hasil akurasi dengan kesesuaian penuh sebesar $47 \%$, sedangkan akurasi dengan kesesuaian sebagian sebesar $32 \%$ dan tidak akurat sebesar $21 \%$. Hasil akurasi tersebut sangat bergantung pada data rekam medis karena menggunakan metode probabilitas. Ketidakakuratan yang dihasilkan oleh sistem tersebut sudah ditanggulangi dengan fitur perbaharui hasil, 
sehingga sistem ini bersifat fleksibel.

Berdasarkan hasil penelitian pengembangan dan kesimpulan, dapat disarankan kepada pembaca yang ingin mengembangkan bahwa data rekam medis sistem hanya dari satu dokter, diharapkan untuk pengembang selanjutnya dapat mengembangkan sistem pendukung keputusan diagnosa penyakit gangguan jiwa dan untuk keoptimalan hasil analisis sistem diharapkan pengembang selanjutnya menggunakan data sampel lebih dari 100 data rekam medis.

\section{REFERENSI}

[1] Badan Pusat Statistik Provinsi Bali, 2016.

[2] Dinas Kesehatan Provinsi Bali, 2016.

[3] I. N. Hidayati, "Pemanfaatan Teori Bukti Dempster-Shafer Untuk Optimalisasi Penggunaan Lahan Berdasarkan Data Spasial dan Citra Multisumber," Embryo Vol 7 No. 1, Juni 2010.

[4] K. Fudyartanta, "Psikologi Umum I \& II," PUSTAKA PELAJAR, Yogyakarta, 2011.

[5] N. S. Diniari, "Psikodinamika Gangguan Jiwa," 2015.

[6] Kusrini, "Konsep dan Aplikasi Slstem Penunjang Keputusan," Andi Offset, Yogyakarta, 2007.

[7] V. Christian, "Sistem Pendukung Keputusan Kenaikan Jabatan Pada PT Bank Central Asia Tbk. (BCA) Menggunakan Metode Analityc Heararchy Process," UDINUS, p. 21, 2014.

[8] R. Wells, "Makalah Decision Support System / Sistem Pendukung Keputusan," 2016.

[9] D. N. Sulistyaningrum, "Sistem Pendukung Keputusan Rotasi Tanaman Menggunakan Metode Analytical Hierarchy Process (AHP)," 2016.

[10] R. Arief, "Teori Dempster-Shafer," 2013.
[11] E. S. Y. Pandie, "SISTEM INFORMASI PENGAMBILAN PENGAJUAN ALGORITMA NEIGHBOUR KEPUTUSAN (STUDI KASUS: KOPERASI SIMPAN PINJAM)," Universitas Diponegoro, 2012.

[12] L. M. D. Kusumayanti, "Pengembangan Sistem Pendukung Keputusan Kredit Konsumtif Dengan Metode Naive Bayes (Studi Kasus: PT. Bank Pembangunan Daerah (BPD) Bali Cabang Tabanan)," JANAPATI, p. 110, 2016. 